\title{
Effect of Internal Audit Practices on Financial Performance of Banks in Ghana
}

\author{
Eleazer Fianko Ofei ${ }^{1}$ Mark Andoh - Owusu ${ }^{2}$ Carl-Reindolph Asante ${ }^{3}$ \\ ${ }^{1}$ Lecturer AIT Business School, Accra Institute of Technology - Ghana \\ ${ }^{2}$ Lecturer AIT Business School, Accra Institute of Technology - Ghana \\ ${ }^{3}$ Lecturer AIT Business School, Accra Institute of Technology - Ghana
}

ABSTRACT

Internal audit (IA) practices are considered as one of the key measures necessary for promoting healthy business activities. In this study, the researchers examine the effect of internal audit practices on the performance of banks in Ghana. The study used a sample of 154 respondents from 5 selected banks, the study adopted the quantitative research approach, data was analyzed using inferential statistical methods such as correlations and regression analysis. The study results indicate that there is a strong positive effect of monitoring, risk assessment and information and communication on the financial performance of banks in Ghana, whereas there was no significant effect of control environment and control activities on the financial performance of banks in Ghana. The study recommends that the management of banks should strengthen the control environment, by enhancing the policies and procedures adopted by the banks in safeguarding assets and properties, there is the need to continuously review the existing policies, procedures and activities performed to ensure that they have not outlived their usefulness in the wake of changing competitions and advancement in technology and management orientation.

Keywords: Internal Control, Internal Control Environment, Internal Audit, Financial Performance

DOI: DOI 10.35942/ ijcfa.v2i2.131

\section{Cite this Article:}

Ofei, E., Owusu, M., \& Asante, C. (2020). Effect of Internal Audit Practices on Financial Performance of Banks in Ghana. International Journal of Current Aspects in Finance, Banking and Accounting, 2(2), 46-58. https://doi.org/10.35942/ijcfa.v2i2.131

\section{Introduction}

Internal Control is defined as all the policies and procedures adopted by the directors and management of an entity to assist in achieving their objective of ensuring, as far as practicable, the orderly and efficient conduct of its business, including adherence to internal policies, the safeguarding of assets, the prevention and detection of frauds and errors, the accuracy and completeness of accounting records, and the timely preparation of reliable financial information. (Ofori, 2011). Internal controls refer to the measures instituted by an organization to ensure attainment of the entity's objectives, goals and missions. They are a set of policies and procedures adopted by an entity in ensuring that an organization's transactions are processed in the appropriate manner to avoid waste, theft and misuse of organization resources. Internal audit plays a vital role in ensuring that the right activities are done in an organization leading to ensuring that assets and resources are protected enhancing the financial performance of institutions. Organizations with 
International Journal of Current Aspects in Finance, Banking and Accounting, Volume 2, Issue 2, 2020 PP 46-58, ISSN 2707-8035

iJCAB

weak internal control systems have in recent years had their financial performance affected greatly with some institutions severely affected by the nature of weak systems in place (Ofori, 2011).

According to Ahmed \& Ng'anga (2019), internal control environment sets the tone for or basis for carrying out inter control across all organizations. Therefore organizations need to develop their internal controls with complete emphasis on the internal control environment ensuring that the right activities are put in place to ensure the protection of assets and enhancing of the profit potential of these organizations. Similarly, Ahmed \& Ng'anga, (2019) stated that monitoring in organizations is an essential activity that needs close attention if organizations would like to see an increase in the financial performance of their organizations. This implies that weak monitoring activities and processes have the potential of opening up the system for financial malfeasance that are likely to affect the financial stability of the organization. In the study by Ahmed \& Ng'anga, (2019) they pointed out that one key aspect of risk assessment in organizations is the ability for management to be able to identify risk and control risk, this is essential as a weak risk control systems set the avenue for misappropriation and misuse of funds which affects the financial performance of these institutions. In managing the financial performance of organizations, these organizations need to adopt an effective and efficient information communication systems to ensure that timely information is generated and reported for necessary action to be taken (Ahmed \& Ng'anga, 2019). Organizations need to communicate or report to shareholders of the institutions on the nature of activities and performance to create trust and confidence (Ahmed \& Ng'anga, 2019).

Financial performance in relation to global macro-financial vulnerabilities remained broadly subdued in spite of a slowdown in global economic growth. In 2019, heightened uncertainties emerging from geopolitical factors including the US-China trade tensions and prolonged Brexit negotiations slowed down economic activities and dampened global economic growth. Improvement in global financing conditions induced by an accommodative monetary policy stance, in most advanced economies, moderated downside risks to global growth and financial stability (BoG, 2019). Favourable macro-financial developments reduced vulnerabilities stemming from the domestic economy. Domestic output remained strong at 6.5 percent in 2019, while headline inflation continued to decline. In the review period, a balance of payments surplus was also observed as a result of a narrowing of the current account deficit. This is expected to support stability of the local currency - the Cedi - and lead to improvements in the Gross International Reserves. On credit developments, the Credit-to-GDP gap was below its potential level, indicating that the economy has the capacity to absorb more credit without a significant build-up of risks. The banking sector remained sound and robust to severe stress test scenarios, featuring significant increases in credit impairments, extreme movement in interest and exchange rates, and liquidity pressures. Also risk emanating from cross-border exposures remained contained. The broad level of risk containment in the banking sector was underpinned by strong capital and liquidity positions, placement of offshore funds with stable institutions and improvement in asset quality, earnings and efficiency. Going forward, favourable economic prospects in the near term and the gradual phase in of Basel II/III are expected to firm up gains achieved through the banking sector reforms (BoG, 2019).

The performance of the insurance sector broadly improved in 2019, with the outlook for premium growth, risk retention and insurance penetration remaining positive. Policy reforms and a favourable operational environment improved premium income, assets and capital positions. Despite these improvements, persistent underwriting losses and declining investment yields 
International Journal of Current Aspects in Finance, Banking and Accounting, Volume 2, Issue 2, 2020 PP 46-58, ISSN 2707-8035

[IJCAB

continued to drag on profitability. In the near to medium term, the introduction of the new minimum capital regime is expected to improve efficiencies through consolidation. In addition, insurance penetration is expected to improve on the back of a broad-based introduction of innovative insurance products and comprehensive policy reforms aimed at strengthening the insurance industry. Driven by strong growth in private pension funds, the pensions sector continued to expand in spite of emerging vulnerabilities from weak investment outturns, weakened contribution growth and rising benefit payout. Notwithstanding these vulnerabilities, the pensions sector exhibits a strong potential for growth in the medium to long term as policy measures are targeted at increasing contributions flows and inclusion (BoG, 2019). In the capital market, the performance of the stock exchange declined in the period under review posing a risk to large equity holders such as the public pension fund. The declining performance reflects the reductions in the size, access, and efficiency dimensions of the stock market. Despite these developments, capital flight remained low as foreign investors increased their presence on the domestic capital market, partly due to restored banking sector stability and favourable macroeconomic prospects. The financial sector also continued to witness policy reforms aimed at safeguarding financial and macroeconomic stability. The reforms included the resolution of insolvent institutions, increase in minimum capital requirements, enhancement of supervisory regimes, establishment of a regulatory forum for Anti-Money Laundering and Combatting the Financing of Terrorism, establishment of a Financial Stability Advisory Council, and operationalization of the Ghana Deposit Protection Corporation, among others (BoG, 2019)

\section{Problem Statement}

Internal audit plays a vital role in ensuring that the right activities are done in an organization leading to ensuring that assets and resources are protected, enhancing the financial performance of institutions. Organizations with weak internal control systems have in recent years had their financial performance affected greatly with some institutions severely affected by the nature of weak systems in place. The Banking sector of Ghana is a key sector that controls the financial sector by providing needed support for individuals and businesses and providing financial inclusion. The sector has in recent years gone through a lot of challenges, with banks unable to meet up with the minimum capital requirements, leading to the consolidation of some banks and others and others absorbed by the Ghana commercial banks with others downgraded to savings and loans etc. Aside this, the bank of Ghana had to come to the support of the banks with 10.98 billion Cedis which is equivalent to 2.1billon dollars, (Bank of Ghana, 2018). This raises concerns on the effectiveness of the internal audit of these banks and also the sustainability of the operations of these banks and calls for stringent measures to be taken to ensure that such drain on the national purse does not pressure. This study examines the relationship between the internal audit practices of these banks and the financial performance and seeks to provide a recommendation on the way forward.

Previous studies conducted on internal audit such as the study by Ahmed \& Ng'anga, (2019) was conducted in the local government which is indifferent sector other than the banking sector. The study was also limited to only four of the internal control activities excluding the assessment of control activities which is also a key component of the internal control activities. The study adopted three theories, the Agency Theory, Attribution Theory and Procedural Justice Theory, but failed to examine the stewardship theory, stakeholder theory and institutional theories which presents the need for approaching the study from different theoretical perspectives. The study is further limited as it only focused on county government agencies and did not consider all other institutions in 
International Journal of Current Aspects in Finance, Banking and Accounting, Volume 2, Issue 2, 2020 PP 46-58, ISSN 2707-8035

[IJCAB

Kenya. Similarly, the study was conducted in Kenya which is an African country but does not fit into the Ghanaian context as the environments are different in terms of rules, regulations and banking laws.

In other related studies, Kinyua, Gakure, Gekara, \& Orwa, (2015) examined the Effect of Internal Control Environment on the Financial Performance of Companies Quoted in the Nairobi Securities Exchange. The study focused on companies listed on the Kenyan stock exchange without specifically considering the banking sector or the Ghanaian context. The study also used stratified random sampling which is a procedure that allows for some level of bias. Mbilla, Nyeadi, Gbegble, \& Ayimpoya, (2020) assessed the Impact of Monitoring, Information and Communication on Banks Performance in Ghana. Although the study was done considering banks in Ghana, the study failed to consider all five internal control dimensions, this study only considered two of the dimensions which are information and communication and monitoring. From the knowledge gaps identified in the previous studies, there is a need for further studies in the area of internal audit in the Ghanaian context focusing on all five internal control variables.

\section{Objectives of the Study}

The objective of the study is to

i. Determine the effect of control environment on the financial performance of banks in Ghana.

ii. Asess the effect of control activities on the financial performance of banks in Ghana.

iii. Determine the effect of monitoring activities on the financial performance of banks in Ghana.

iv. Examine the effect of risk management activities on the financial performance of banks in Ghana.

v. Determine the effect of information and communication systems on the financial performance of banks in Ghana.

\section{Theoretical Review}

Internal audit is explained as the examination, monitoring and analysis of activities associated with the company's operation, together with its business structure, employee behaviour and information systems. It is intended to appraise what a company is doing to identify potential threats to the organization's strength and success and to come out with propositions for addressing the risk related to those threats to reduce costs. Another definition, internal audit can be referred to as an independent, objective assurance and consulting activity intended to create value and enhance an organization's operations. It aids an organization to achieve its objects by bringing a systematic, disciplined approach to assess and enhance the effectiveness of risk management, control, and governance processes. To ensure this is done, the work of internal auditors is to work with management systematically, consistently review the systems and operations (Barua, Rama, and Sharma 2010; Norman, Rose, and Rose 2010).

\subsection{Agency Theory}

This theory has its origin in the principles of the Modern Corporation. It is based on the idea that players in a firm can be categorized into two groups: the principals who are the owners of the firm and the agents who manage the firm (Jensen \& Meckling, 1976; Eisenhardt, 1998). The agency theory explains that a principal-agent relationship leads to conflict which can then result in extra costs associated with resolving the conflict between principals and agents (Jensen \& Meckling, 
International Journal of Current Aspects in Finance, Banking and Accounting, Volume 2, Issue 2, 2020 PP 46-58, ISSN 2707-8035

[IJCAB

1976; Eisenhardt, 1998). It has been argued that agency theory has been the most dominant issue in corporate governance and principal-agent theory is generally considered the starting point of this debate. Agency theory hypothesizes that in the modern corporation, in which share ownership is widely held, managerial actions depart from those required to maximize shareholder returns (Mallin, 2007). This theory is adopted because, from the agency theory perspective, non-executive directors and independent directors contribute to effective corporate governance by exercising control over senior managers' decision-making. After all, they are seen as the check and balance mechanism to enhance the board's effectiveness.

\subsection{Stewardship theory}

The stewardship theory of corporate governance holds that, because people can be trusted to act in the public good in general and in the interests of their shareholders in particular, it makes sense to create management and authority structures that, because they provide unified command and facilitate autonomous decision making which enables companies to act quickly and decisively to market opportunities. This approach leads, for instance, to the combination of the roles of CEO and board chairperson and for audit committees to be either non-existent or lightweight. Stewardship theory assumes that managers are honest, and motivated more by intrinsic rewards than extrinsic rewards, and self-motivated to maximize collective interests (Nicholson and Kiel, 2003; Davis-et al., 2003). The stewardship theory is adopted for this study because it strongly argues that managers and boards of directors are good stewards of a firm and they should be given utmost trust.

\subsection{Institutional Theory}

Institutional theory is one of the dominant perspectives within organisation and management theory (Greenwood et al., 2008); it has been widely utilized to assess the practical influence of Corporate Governance codes (Solomon, 2013). Beasley et al. (2009) explain that institutional theory is uniquely positioned to contribute to researchers' knowledge of CG because of the insights it offers into the nature of authority and control structures. For example, Beasley et al. (2009) argue that institutional theory confirms that governance structures are often primarily symbolic/ceremonial; their legitimacy is paramount, but the formal processes are only loosely coupled with true monitoring. This theory is adopted because there is a consensus among researchers that institutional theory offers a useful lens for investigating the role and activities of Internal Audit, particularly when used in conjunction with agency theory.

\section{Empirical Studies}

Ahmed \& Ng'anga, (2019) examined the effect of Internal Control Practices and Financial Performance of County Governments in the Coastal Region of Kenya. The study adopted a descriptive research design. The target population of the study was respondents was carried out using primary data, the data was collected using questionnaires. Analysis of the data was both descriptive and inferential analysis. The study found a positive and significant effect between risk assessment, monitoring, control environment, information and communication on financial performance. The study concluded that the risk identification and mitigation play the most significant role in influencing the financial performance of the County governments. The study recommended that the management of Counties should put in place cost-effective measures for timely risk identification and effective risk mitigation to ensure that their financial performance is not impacted negatively. The study by Ahmed \& Ng'anga, (2019) was conducted in the local government which is in a different sector other than the banking sector, the study did not also 
International Journal of Current Aspects in Finance, Banking and Accounting, Volume 2, Issue 2, 2020 PP 46-58, ISSN 2707-8035

[IJCAB

consider control activities, but considered only four out of the five internal control activities, hence limiting the study from the assessment of control activities which is also a key component of the internal control activities. The study adopted three theories, the Agency theory, attribution theory and procedural justice theory, but failed to examine the stewardship theory, stakeholder theory and institutional theories which presents the need for approaching the study from different theoretical perspectives. The study is further limited as it only focused on county government agencies and did not consider all other institutions in Kenya. Similarly, the study was conducted in Kenya which is an African country but does not fit into the Ghanaian context as the environments are different in terms of rules, regulations and banking laws.

Kinyua, Gakure, Gekara, \& Orwa, (2015) examined the Effect of Internal Control Environment on the Financial Performance of Companies Quoted in the Nairobi Securities Exchange. to realize the objective of this study, the researcher specifically looked at the following objectives: control environment, internal audit, risk management, internal control activities and role of corporate governance controls on the financial performance of quoted companies in Kenya. The study adopted a survey research design. The study population was all 62 companies quoted in NSE. The study used a sample of 38 companies from a target population of 62 companies quoted in NSE. The sample was drawn using a stratified random sampling technique. The study relied on both primary and secondary data. Primary data was collected using structured questionnaires while the Secondary data was extracted from audited annual reports, publications and document analysis. Data analysis used both descriptive and inferential statistics. Frequency tables were prepared, averages determined and tests of hypothesis like ANOVA, chi-square, correlation analysis were done. The results and findings concluded that there was a significant association between internal control environment and financial performance and recommends that internal control environment should be enhanced to further improve the financial performance of companies quoted in Nairobi Securities Exchange. The study focused on companies listed on the Kenyan stock exchange without specifically considering the banking sector the study also used stratified random sampling which is a procedure that allows for some level of bias.

Mbilla, Nyeadi, Gbegble, \& Ayimpoya, (2020) assessed the Impact of Monitoring, Information and Communication on Banks Performance in Ghana. The study was quantitative, the sample size was 300 representatives from twelve listed banks. A descriptive study was done and regression analysis was performed on the field data. The study findings indicate that Information and communication have a weak significant effect on financial performance. There was no significant effect between Monitoring and financial performance. The study, therefore, recommends that managers of listed Banks must invest more on information and communication to improve performance. Although the study was done considering banks in Ghana, the study failed to consider all five internal control dimensions, this study only considered two of the dimensions which are information and communication and monitoring. Collins, (2014) examined the effect of internal control on the financial performance of microfinance institutions in Kisumu central constituency, Kenya. The specific objectives included; to determine the extent of internal control systems application; to assess the adequacy and effectiveness of the established control activities, and to determine the relationship between the internal control and financial performance of microfinance institutions. The independent variable was internal control (Control Environment, Control Activities and Information and communication) and the dependent variable was financial performance (Liquidity). Descriptive and correlation research design was adopted and a case study was done on the chosen institutions. Convenience sampling technique was used and a total of 7 
International Journal of Current Aspects in Finance, Banking and Accounting, Volume 2, Issue 2, 2020 PP 46-58, ISSN 2707-8035

\section{[IJCAB}

institutions were chosen from a total population of 18 micro-finance institutions and a total of 35 respondents (five respondents per institution; 2 midlevel managers and 3 staff members) chosen purposively for this study. Questionnaires were used to collect primary data and data collected analyzed using correlation and presented through tables. Findings revealed that there is a positive relationship between internal control (Our institution has an accounting and financial management Information system). The study recommends that the institutions should tighten controls to tend towards a $100 \%$ debt collection. The study further points out that keen attention should be paid to adopt more efficient management information systems.

Mire, (2016) assessed the Effects of Internal Control System on The Organizational Performance of Remittance Companies in Mogadishu-Somalia. The study would adopt quantitative research with the specific research design being descriptive. The population of the study was the classified remittance companies located in Bakara market, and there were 15 remittance companies in the Bakara market, the employees who worked in 15 remittance companies were 402 employees. The sampling technique used was purposive sampling. Primary data was collected by use of questionnaires which were administered through drop and pick method. Data screening was done to identify any missing data and was further tested for reliability and normality. Data was analyzed using the SPSS version. The study recommended that there is need for the remittance companies in Mogadishu to increase their control environment; risk assessment and control activity as it was founded that these variables positively affects the organizational performance of remittance companies in Mogadishu. The study failed to consider all five internal control variables, the study also used customer satisfaction and employee satisfaction as dependent variables without considering return on assets, the study did not also focus on the baking sector.

\section{Conceptual Framework}

Conceptual framework of the study is as follows;

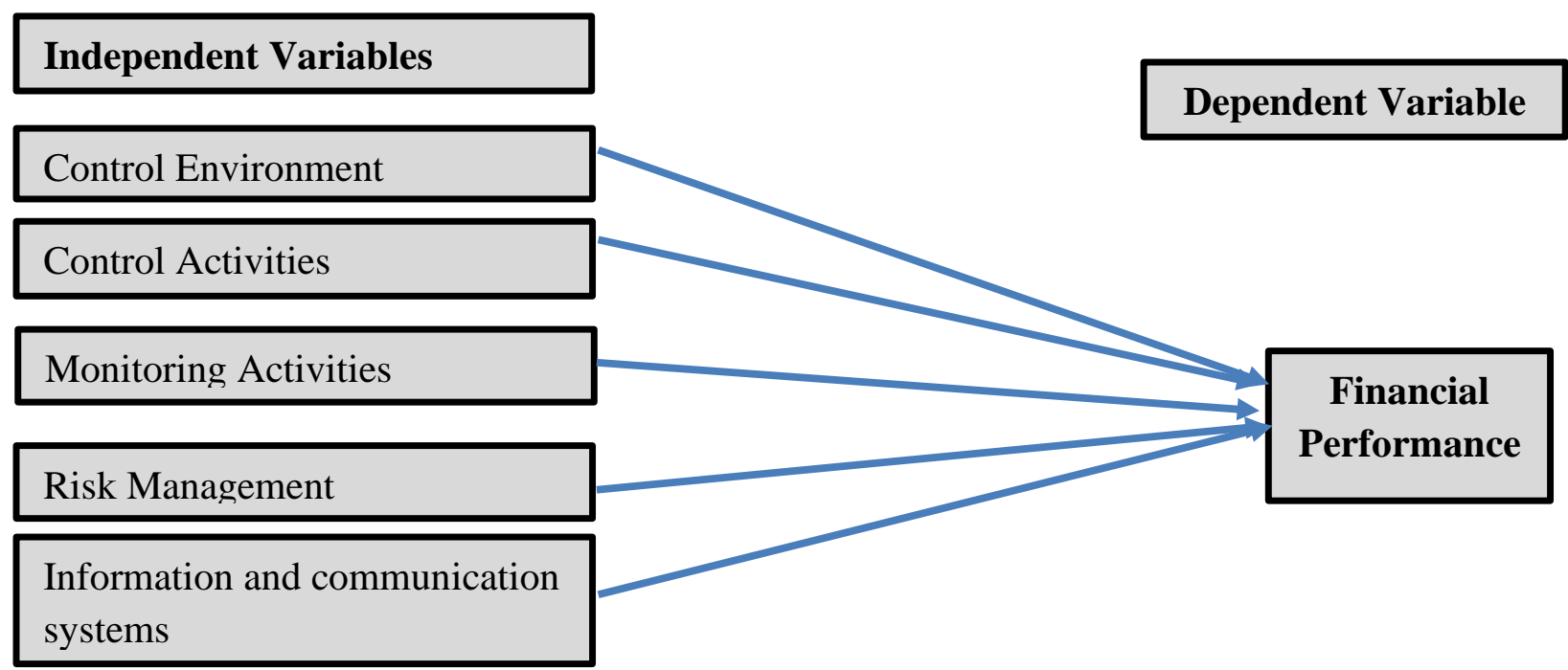

Figure 1: Conceptual Framework

The study is grounded on the Committee of Sponsoring Organizations of Tread Way Commission (COSO) Model introduced by COSO committee in 1992 and modified in 2013. Through a comprehensive review of literature Mire, (2016); Collins, (2014); Mbilla, Nyeadi, Gbegble, \& Ayimpoya, (2020); Kinyua, Gakure, Gekara, \& Orwa, (2015); Ahmed \& Ng'anga, (2019) the study identified five major independent variables; Control Environment (CE), Control Activities 
International Journal of Current Aspects in Finance, Banking and Accounting, Volume 2, Issue 2, 2020 PP 46-58, ISSN 2707-8035

[IJCAB

(CA), Risk Assessment (RA), Information \& communication (IAC) and Monitoring (MO) that may affect Bank's Financial Performance.

\section{Methodology}

The study adopts a descriptive survey design to describe the relationship between internal audit practices and financial performance of banks in Ghana, a quantitative research approach was adopted for the study. This design is also well-thought-out as appropriate since it permits the researcher to produce data through the standardized collection procedures based on structured research instrument(s) and well-defined study concepts and variables. The study used a sample of 154. This size was informed by Hair, Sarstedt, Ringle, \& Mena, (2011) who advocated that in a survey study, a sample of 100 is enough to generate the statistical strength of the study. Again, the sample size chosen was based on recognized sample sizes required for given population size. The study adopted a purposive sampling technique in selecting the banks for the study. The respondents included Managers, Account officers, Auditors and Chief Executive Officers of the respective Banks. The analysis was done using inferential analysis in the form of correlation and regression analysis.

\section{Analysis of Data}

This section discusses the analysis from the data collected, as follows; To test the significant relationship between the independent variables, a correlation analysis was done. The results of the analysis have been captured and presented in the table below;

\section{Table 1 - Correlations}

\begin{tabular}{|c|c|c|c|c|c|c|}
\hline & & $\begin{array}{c}\text { Internal } \\
\text { Control } \\
\text { Environm } \\
\text { ent } \\
\end{array}$ & $\begin{array}{c}\text { Control } \\
\text { Activities } \\
\end{array}$ & $\begin{array}{c}\text { Monitori } \\
\text { ng } \\
\text { Activities }\end{array}$ & $\begin{array}{c}\text { Risk } \\
\text { Assessmen } \\
\mathbf{t} \\
\end{array}$ & $\begin{array}{c}\text { Information } \\
\text { and } \\
\text { Communicati } \\
\text { on Systems }\end{array}$ \\
\hline \multirow{2}{*}{$\begin{array}{l}\text { Internal } \\
\text { Control } \\
\text { Environment }\end{array}$} & $\begin{array}{l}\text { Pearson } \\
\text { Correlation }\end{array}$ & 1 & & & & \\
\hline & $\begin{array}{l}\text { Sig. (2- } \\
\text { tailed) }\end{array}$ & & & & & \\
\hline \multirow[t]{2}{*}{$\begin{array}{l}\text { Control } \\
\text { Activities }\end{array}$} & $\begin{array}{l}\text { Pearson } \\
\text { Correlation }\end{array}$ & $.577^{* *}$ & 1 & & & \\
\hline & $\begin{array}{l}\text { Sig. (2- } \\
\text { tailed) }\end{array}$ & .000 & & & & \\
\hline \multirow[t]{2}{*}{$\begin{array}{l}\text { Monitoring } \\
\text { Activities }\end{array}$} & $\begin{array}{l}\text { Pearson } \\
\text { Correlation }\end{array}$ & $.519^{* *}$ & $.669^{* *}$ & 1 & & \\
\hline & $\begin{array}{l}\text { Sig. (2- } \\
\text { tailed) }\end{array}$ & .000 & .000 & & & \\
\hline \multirow[t]{2}{*}{$\begin{array}{l}\text { Risk } \\
\text { Assessment }\end{array}$} & $\begin{array}{l}\text { Pearson } \\
\text { Correlation }\end{array}$ & $.186^{*}$ & $.175^{*}$ & $.341^{* *}$ & 1 & \\
\hline & $\begin{array}{l}\text { Sig. (2- } \\
\text { tailed) }\end{array}$ & .021 & .030 & .000 & & \\
\hline $\begin{array}{l}\text { Information } \\
\text { and }\end{array}$ & $\begin{array}{l}\text { Pearson } \\
\text { Correlation }\end{array}$ & .071 & .130 & -.009 & $.435^{* *}$ & \\
\hline
\end{tabular}


International Journal of Current Aspects in Finance, Banking and Accounting, Volume 2, Issue 2, 2020 PP 46-58, ISSN 2707-8035

iJCAB

\begin{tabular}{|c|c|c|c|c|c|c|}
\hline \multirow[t]{2}{*}{$\begin{array}{l}\text { Communicatio } \\
\text { n Systems }\end{array}$} & $\begin{array}{l}\text { Sig. (2- } \\
\text { tailed) }\end{array}$ & .383 & .108 & .910 & .000 & \\
\hline & $\mathrm{N}$ & 154 & 154 & 154 & 154 & 154 \\
\hline
\end{tabular}

The Pearson's $\mathrm{r}$ for the correlation between Control environment and monitoring variables is $(0.577$, P-value $<0.05)$ which is close to 1 with a significant value of 0.00 which is less than 0.05 . This shows a fairly strong relationship meaning that changes in one variable are strongly correlated with changes in the second variable. The findings are in line with Kinyua, Gakure, Gekara, \& Orwa, (2015) who examined the Effect of Internal Control Environment on the Financial Performance of Companies Quoted in the Nairobi Securities Exchange The results and findings concluded that there was a significant association between internal control environment and financial performance. The Pearson's $\mathrm{r}$ for the correlation between Control Activities and monitoring variables is $(0.699$, $\mathrm{P}$-value $<0.05)$ which is close to 1 with a significant value of 0.00 which is less than 0.05 . This shows a fairly strong relationship meaning that changes in one variable are strongly correlated with changes in the second variable. However, the study is in variance with the study done Mbilla, Nyeadi, Gbegble, \& Ayimpoya, (2020) who assessed the Impact of Monitoring, Information and Communication on Banks Performance in Ghana and found that there was no significant effect between Monitoring and financial performance. The Pearson's $r$ for the correlation between Monitoring and control environment is $(0.519$, P-value < 0.05 ) which is close to 1 with a significant value of 0.00 which is less than 0.05 . This shows a fairly strong relationship meaning that changes in one variable are strongly correlated with changes in the second variable. The study results were in line with the findings of Mire, (2016) who assessed the Effects of Internal Control System on The Organizational Performance of Remittance Companies in Mogadishu-Somalia, the study found that internal audit positively affected the organizational performance of remittance companies in Mogadishu.

In other to test the effect of internal audit practices on financial performance, regression was done to ascertain the effect. The regression results from the regression analysis done on the effect of internal audit practices is captured below;

Table 2 - Model Summary

\begin{tabular}{|c|c|c|c|c|}
\hline Model & $\mathrm{R}$ & R Square & Adjusted R Square & $\begin{array}{l}\text { Std. Error of the } \\
\text { Estimate }\end{array}$ \\
\hline 1 & $.786^{\mathrm{a}}$ & .617 & .604 & 1.71496 \\
\hline
\end{tabular}

From the model summary, it is observed that the five independent variables explain $78.6 \%$ of the changes or variations in the dependent variable which is performance. by this, it means there are other variables other than the independent variables that account for $21.4 \%$ of variations or changes in the financial performance of the banks. 
International Journal of Current Aspects in Finance, Banking and Accounting, Volume 2, Issue 2, 2020 PP 46-58, ISSN 2707-8035

[iJCAB

Table 3 - ANOVA ${ }^{\mathrm{a}}$

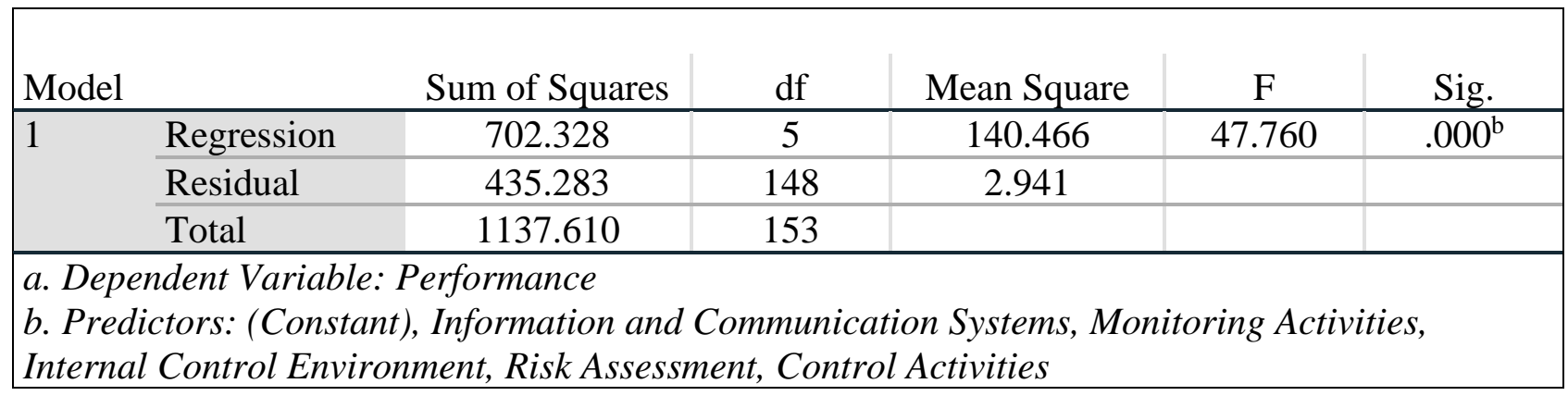

From the ANOVA results, the significance value is $0.000 \mathrm{a}$ which is less than 0.05 , indicates that the model is statistically significant in predicting how the independent variables studied influenced the financial performance of banks in Ghana.

Table 7 - Coefficients ${ }^{\mathrm{a}}$

\begin{tabular}{|c|c|c|c|c|c|c|}
\hline \multirow{2}{*}{\multicolumn{2}{|c|}{ Model }} & \multicolumn{2}{|c|}{$\begin{array}{l}\text { Unstandardized } \\
\text { Coefficients }\end{array}$} & \multirow{2}{*}{$\begin{array}{c}\text { Standardized } \\
\text { Coefficients } \\
\text { Beta } \\
\end{array}$} & \multirow[b]{2}{*}{$t$} & \multirow[b]{2}{*}{ Sig. } \\
\hline & & B & Std. Error & & & \\
\hline \multirow[t]{6}{*}{1} & (Constant) & 5.157 & 1.712 & & 3.012 & .003 \\
\hline & $\begin{array}{l}\text { Internal Control } \\
\text { Environment }\end{array}$ & .043 & .055 & .050 & .788 & .432 \\
\hline & Control Activities & .076 & .049 & .118 & 1.554 & .122 \\
\hline & $\begin{array}{l}\text { Monitoring } \\
\text { Activities }\end{array}$ & -.164 & .053 & -.237 & -3.094 & .002 \\
\hline & Risk Assessment & .348 & .051 & .427 & 6.858 & .000 \\
\hline & $\begin{array}{l}\text { Information and } \\
\text { Communication } \\
\text { Systems }\end{array}$ & .413 & .050 & .494 & 8.326 & .000 \\
\hline
\end{tabular}

From the above regression model, holding internal control environment, control activities, monitoring activities, risk assessment and information communication systems constant, the beta coefficient would 5.157. The established regression equation by the study was $\mathrm{Y}=5.157+$ $0.043 \mathrm{X} 1+0.076 \mathrm{X} 2+-0.164 \mathrm{X} 3+0.348 \mathrm{X} 4+0.413 \mathrm{X} 5$. Where $\mathrm{Y}=$ Financial Performance; $\mathrm{X} 1=$ Control Environment, $\mathrm{X} 2$ = Control Activities, X3=Monitoring Activities, X4=Risk Assessment and X5 = Information and Communication systems. As shown in the table above, it is observed that monitoring has a significant effect on financial performance with $(t=-3.094$, $p$-value $<0.05)$, risk assessment and information and communication systems has a positive significant effect on the financial performance of banks in Ghana with $(\mathrm{t}=6.858$, $\mathrm{p}$-value $<0.05)$ and $(\mathrm{t}=8.326$, $\mathrm{p}$-value $<0.05)$ respectively. The study results are in contrast with the results of Mbilla, Nyeadi, Gbegble, \& Ayimpoya, (2020) who assessed the Impact of Monitoring, Information and Communication on Banks Performance in Ghana and found a weak significant effect of information and communications systems and monitoring on financial performance. Similarly, the study results 
International Journal of Current Aspects in Finance, Banking and Accounting, Volume 2, Issue 2, 2020 PP 46-58, ISSN 2707-8035

iJCAB

were in contrast with the findings of Ahmed \& Ng'anga, (2019) who examined the effect of Internal Control Practices and Financial Performance of County Governments in the Coastal Region of Kenya and found a positive and significant effect between risk assessment, monitoring, control environment, information and communication on financial performance.

It was also observed that there was an insignificant effect of internal control environment and control activities on the financial performance of banks in Ghana with $(t=0.788, p$-value $>0.05)$ and $(\mathrm{t}=1.554$, $\mathrm{p}$-value $>0.05)$ respectively. The study results are in line with the study of Collins, (2014) who examined the effect of internal control on the financial performance of microfinance institutions in Kisumu central constituency, Kenya, who found a positive relationship between internal control. The study findings are in line with the study done by Kinyua, Gakure, Gekara, \& Orwa, (2015) who examined the Effect of Internal Control Environment on the Financial Performance of Companies Quoted in the Nairobi Securities Exchange. Their study found that there was a significant association between internal control environment and financial performance and recommends that internal control environment should be enhanced to further improve the financial performance of companies quoted in Nairobi Securities Exchange.

\section{Conclusions}

The study concludes that risk assessment plays a vital role in the management of financial performance in banks, hence there is the need to pay more attention to the identification of risk and other risk management processes to ensure that financial resources are properly protected. Monitoring is also seen as an effective means through which resources of organizations can be managed. Hence to achieve corporate goals, monitoring activities need to be enhanced to ensure that all aspects of operations and transactions are monitored and are in line with laid down procedures and processes. The study results show that the role of information and communication systems cannot be downplayed, it is an essential part of the systems which need to be resourced and enhanced to guarantee the provision of the right information for decision making. Similarly, the study concludes that control environment and control activities need to be improved to ensure the system is fully safeguarded. It is also concluded that there are other factors other than internal audit practices that affect the performance of banks in Ghana.

\section{Recommendations}

The study recommends that the management of banks should strengthen the control environment, by enhancing the policies and procedures adopted by the banks in safeguarding assets and properties, there is the need to continuously review the existing policies, procedures and activities performed to ensure that they have not outlived their usefulness in the wake of changing competitions and advancement in technology and management orientation. The banks should appraise continuously the control activities to ensure that the activities are up to date and up to the task they are designed to perform. It is further recommended that banks integrate computerized softwares that has the potential of backing up and providing maximum security and safeguards for assets of the banks and their clients. The study is without limitations, the study focused on five banks, it is recommended that future studies consider expanding the scope to include the entire banking sector. 
International Journal of Current Aspects in Finance, Banking and Accounting, Volume 2, Issue 2, 2020 PP 46-58, ISSN 2707-8035

[IJCAB

\section{References}

Ahmed, S. O., \& Ng'anga, P. (2019). Internal Control Practices and Financial Performance of County Governments in the Coastal Region of Kenya. International Journal of Current Aspects, 29-41.

Asare, T. (2009). Internal auditing in the public sector: Promoting good governance and performance improvement. International Journal on Governmental Financial Management, 3(1), 15-27

Barua, A., Rama, D. V. and Sharma, V. (2010). Audit committee characteristics and investment in internal auditing. Journal of Accounting and Public Policy, 29, pp. 503-513.

Bank of Ghana. (2018) Banking reforms and regulatory framework-Ghana

Bank of Ghana Financial Stability Report, December https://www.bog.gov.gh/wp-content/uploads/2020/09/FinancialStability-Review-Dec-2019.pdf

Beasley, M. S., J. V. Carcello, D. R. Hermanson, and T. L. Neal. (2009). The Audit Committee Oversight Process. Contemporary Accounting Research 26 (1):65-122.

Collins, O. O. (2014). Effect of internal control on the financial performance of microfinance institutions in Kisumu central constituency, Kenya. Scholarly Journal of Scientific

Committee of Sponsoring organization. (2013). - Internal control / integrated framework executive summary. Committee of Sponsoring Organisation of the Treadway Commission (Coso) (pp. 1-8).

Corporate Governance Directive. (2018) Bank of Ghana Corporate Governance Directive.

Davis, J., Schoorman, F. \& Donaldson, L. (2003) Towards a stewardship theory of management. Academy of Management Review, 22, vol. 1 pp. 20-47

Eisenhardt, T. (1998) Larger boards size and decreasing firm value in small firms. Journal of Financial Economics, 48, 35-54.

Greenwood, R., Oliver, C., Suddaby, R., \& Sahlin-Andersson, K. (2008). The SAGE Handbook of Organizational Institutionalism. London: Sage Publication Ltd, 2007.

Hair, J. F., Sarstedt, M., Ringle, C. M., \& Mena, J. A. (2011). An assessment of the use of partial least squares structural equation modelling in marketing research. Academy of Marketing Science, 414-433.

Jensen, M. C., \& Meckling, W. H. (1976). Theory of the firm: managerial behaviour, agency costs and ownership structure. Journal of Financial Economics, 3(4), 305-360.

Kinyua, J. K., Gakure, R., Gekara, M., \& Orwa, G. (2015). Effect of Internal Control Environment on the Financial Performance of Companies Quoted in the Nairobi Securities Exchange. International Journal of Innovative Finance and Economics Research, 29-48.

Mallin, C. (2007) Corporate Governance $2^{\text {nd }}$ edition. Oxford University Press, Oxford UK 
International Journal of Current Aspects in Finance, Banking and Accounting, Volume 2, Issue 2, 2020 PP 46-58, ISSN 2707-8035

[JCAB

Mbilla, S. A., Nyeadi, J. D., Gbegble, M. K., \& Ayimpoya, R. N. (2020). Assessing the Impact of Monitoring, Information and Communication on Banks Performance in Ghana. Asian Journal of Economics, Business and Accounting, 58-71.

Mire, H. A. (2016). Effects of Internal Control System on The Organizational Performance of Remittance Companies in Mogadishu-Somalia. Journal of Business Management, 153-167.

Nicholson, G.J, \& Kiel, G. C. (2003). Board Composition and Corporate Performance: How the Australian Experience Informs Contrasting Theories of Corporate Governance. Corporate Governance Vol.11, No.3 Pp. 189-205.

Norman, S. C., Rose, A. M., \& Rose, J. B. (2010). Internal audit reporting lines, fraud risk decomposition, and assessments of fraud risk. Accounting, Organizations and Society, 35(5): 546-557.

Ramachandran, J., Subramanian, R., \& Kisoka, I.J. (2012): Effectiveness of Internal audit in Tanzanian Commercial Banks.

Sarens, G. \& Beldee, I. (2006b). 'The Relationship between internal audit and senior management: a qualitative analysis of expectations and perceptions, 'International Journal of Auditing, Vol. 10, No. 3, pp. 219-241

Solomon, J., (2013). Corporate Governance and Accountability 4th ed. Chichester, UK: John Wiley \& Sons.

Ofori, W. (2011). Effectiveness of internal controls: perception or reality. Journals of Business, 30-45.

This is an open-access article published and distributed under the terms and conditions of

the (c) (7) \&) Creative Commons Attribution 4.0 International License of United States unless otherwise stated. Access, citation and distribution of this article is allowed with full recognition of the authors and the source. Authors seeking to publish with an Internationally Peer Reviewed Journals should consider https://www.ijcab.org/ by writing to the Editor at editor@ijcab.org or submitting online at https://journals.ijcab.org/journals/index.php. The articles must be quality and meet originality test. 